\title{
Corrigendum: On the calculation of $x$-ray scattering signals from pairwise radial distribution functions (2015 J. Phys. B: At. Mol. Opt. Phys. 48 244010)
}

Dohn, Asmus Ougaard; Biasin, Elisa; Haldrup, Kristoffer; Nielsen, Martin Meedom; Henriksen, Niels Engholm; Møller, Klaus Braagaard

Published in:

Journal of Physics B: Atomic, Molecular and Optical Physics

Link to article, DOI:

$10.1088 / 0953-4075 / 49 / 5 / 059501$

Publication date:

2016

Document Version

Peer reviewed version

Link back to DTU Orbit

Citation (APA):

Dohn, A. O., Biasin, E., Haldrup, K., Nielsen, M. M., Henriksen, N. E., \& Møller, K. B. (2016). Corrigendum: On the calculation of $x$-ray scattering signals from pairwise radial distribution functions (2015 J. Phys. B: At. Mol. Opt. Phys. 48 244010). Journal of Physics B: Atomic, Molecular and Optical Physics, 49(5), [059501]. https://doi.org/10.1088/0953-4075/49/5/059501

\section{General rights}

Copyright and moral rights for the publications made accessible in the public portal are retained by the authors and/or other copyright owners and it is a condition of accessing publications that users recognise and abide by the legal requirements associated with these rights.

- Users may download and print one copy of any publication from the public portal for the purpose of private study or research.

- You may not further distribute the material or use it for any profit-making activity or commercial gain

- You may freely distribute the URL identifying the publication in the public portal 


\title{
Corrigendum to: "On the Calculation of X-ray Scattering Signals from Pairwise Radial Distribution Functions"
}

\author{
Asmus O. Dohn *1, Elisa Biasin ${ }^{2}$, Kristoffer Haldrup ${ }^{2}$, Martin M. \\ Nielsen $^{2}$, Niels E. Henriksen ${ }^{1}$, and Klaus B. Møller ${ }^{\dagger 1}$ \\ ${ }^{1}$ Department of Chemistry, Technical University of Denmark, \\ Kemitorvet 207, 2800, Kgs. Lyngby \\ ${ }^{2}$ Department of Physics, Technical University of Denmark, Fysikvej \\ 307, 2800, Kgs. Lyngby
}

November 12, 2015 
When we in Eq. (20) split up the scattering signal into contributions from solvent-solvent terms, solute-solvent (cross) terms, and solute-solute terms, each atom (type) belongs to either the solvent or the solute. Hence, the scattering signal contribution form the solute-solvent (cross) terms, Eq. (20b), should read:

$S_{\mathrm{c}}(q)=2 \sum_{l}^{u} \sum_{m}^{v} f_{l}(q) f_{m}(q) \frac{N_{l} N_{m}}{V} 4 \pi \int_{0}^{R_{\mathrm{box}}} r^{2}\left[g_{l, m}(r)-1\right] \frac{\sin (q r)}{q r} d r$ 